\title{
Introduction of David G. Nathan and the 2003 John Howland Award
}

\author{
FREDERICK H. LOVEJOY, JR.
}

President Chesney, members, and guests, it gives me particular pleasure and fills me with great pride to present to you the winner of the John Howland Award, Dr. David Gordon Nathan (Fig. 1).

In a brief 5 minutes, I offer a thumb-nail sketch. David Nathan was born in Boston. He attended Phillips Andover Academy and then proceeded to Harvard College, where he majored in English. He then crossed the Charles River to the Harvard Medical School, achieving his MD in 1955. He entered internship in medicine at the Peter Bent Brigham Hospital before proceeding to the National Cancer Institute. There he was "ordered" into hematology. On returning to the Brigham for senior residency and faculty appointment, his interest in red cell disorders brought him into contact with Louis K. Diamond. On Dr. Diamond's retirement in 1968, Dr. Nathan became chief of the Division of Hematology/Oncology, a position he held for 18 years. In 1985, he was called to the chair of the Department of Pediatrics at Harvard Medical School and physician-in-chief at the Boston Children's Hospital. He served with immense distinction in this capacity for 10 years before moving to become president of the Dana Farber Cancer Institute from 1995 to 2000 .

Dr. Nathan's contributions to academic medicine have been Herculean. He has defined an important area of scholarship in hematology, trained an entire school of pediatric hematologists, and made major contributions to the discipline of pediatrics and residency training. He has built institutions and training programs for physician/scientists and has been a remarkable national leader in academic medicine.

His contributions to original scholarship have included elucidation of the pathophysiology of $\beta$ thalassemia, development with Orkin and Kan the first prenatal diagnostic test for thalassemia and sickle cell disease, and with Shurin and Propper introduction of constant s.c. infusion of deferoxamine for iron overload. With Oski, Glader, Feig, and Lubin, he made many important contributions to congenital disorders of hematopoiesis. With Sieff, he showed that GM-CSF and IL-3 are necessary co-factors with erythropoietin and with Platt that suppression of erythropoiesis with hydroxyurea will induce fetal $\mathrm{Hb}$ synthesis. With Baehner, he showed in chronic granulomatous disease that hydrogen peroxide is deficient, adversely affecting

Presented at the 2003 Annual Meeting of the Pediatric Academic Societies, Seattle, Washington, U.S.A.

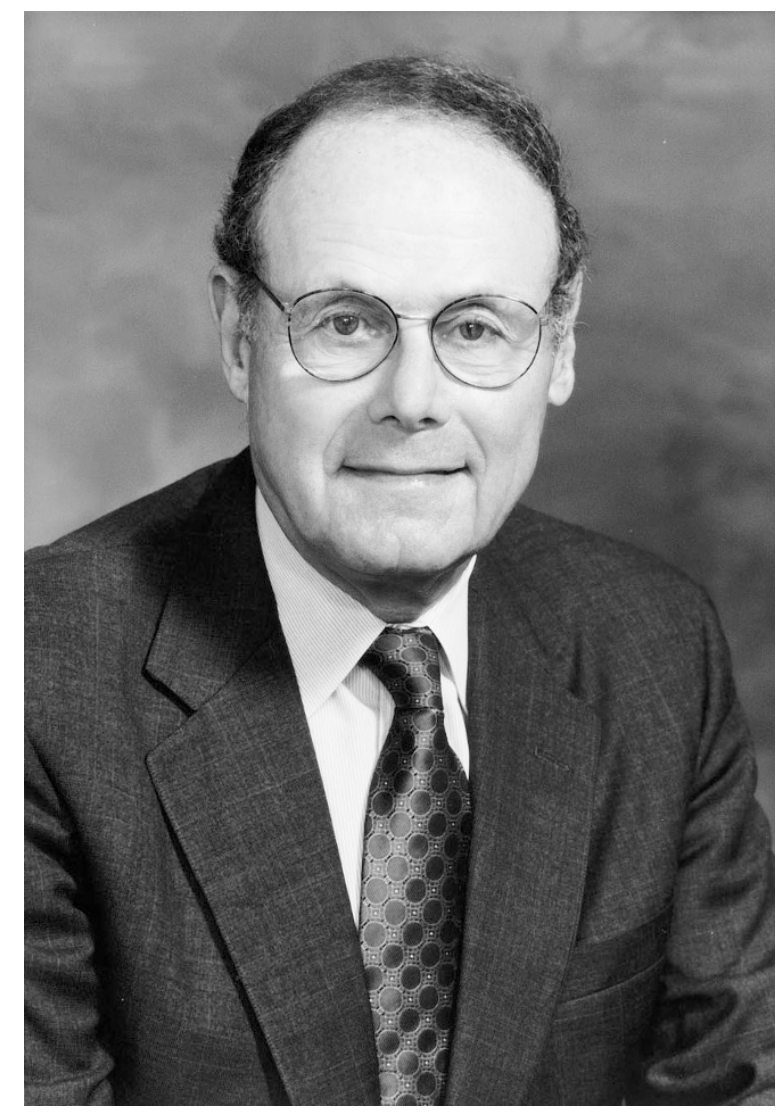

Figure 1. David G. Nathan.

bacterial killing. Finally, with Rosen and Parkman, he initiated the first bone marrow transplant in Wiscott Aldrich syndrome. His contributions to hematology are beautifully captured in his textbook, in its 6th edition, Hematology of Infancy and Childhood, initially edited with his great friend Frank Oski and now with Stuart Orkin. His book Genes, Blood and Courage describes the inquiries into thalassemia, illustrative of the molecular biology revolution in medicine.

Dr. Nathan's contributions to training are exceptional. Between 1966 and 1988, he trained over 102 graduates in pediatric hematology/oncology, 95 of whom remain in academic medicine holding major leadership positions. With Barry Zuckerman, he established the remarkable joint training program in pediatrics between the Boston Children's Hospital and Boston Medical Center, a model for training in general pedi- 
atrics. Since 1985, remarkably $80 \%$ of his over 400 resident trainees have pursued fellowship training, with $70 \%$ remaining in academic medicine.

Perhaps Dr. Nathan's greatest contributions have been in the building of programs and institutions. At Boston Children's Hospital, he synergized scientific investigation, initially with a $30 \%$ enlargement of the Ender's Building through the support of the Howard Hughes Institute and subsequently with the recruitment of top flight scientists, including Mulligan, Harrison, Alt, Majzoub, Fleisher, and the late Wiley and Bernfield, while continuing to support scientists of the caliber of Orkin, Lux, Kunkel, and Geha. In his later years, he engineered the creation of the Dana Farber Harvard Cancer Center involving collaboration of all five Harvard teaching hospitals, the Medical School, and the School of Public Health.

The recipient of numerous awards and honors, including the National Medal of Science and the Stratton Medal from the American Society of Hematology, Dr. Nathan is a past president of the American Society of Hematology and a member of the Institute of Medicine. On his retirement, the trustees of the Dana Farber created the David G. Nathan Chair at the Harvard Medical School. Dr. Edward Benz, an early trainee of Nathan's in the 1970s, is the current president of the Dana Farber Cancer Center.

Finally, on the national scene, he chaired a major task force for Harold Varmus, which led to a new definition of clinical research and remarkable growth in clinical research applica- tions to the National Institutes of Health. He serves on the Medical Advisory Board of the Howard Hughes Medical Institute and as the sole physician member on the Dyson Foundation, assisting its efforts to create new, innovative programs in community pediatrics.

In the early 1990s, he with innovation chaired the Program Committee of the APS/SPR for 2 years at a time when our meetings were threatened. The current result is a vibrant and growing meeting of the PAS. His efforts were recognized by our societies with the David G. Nathan Award in Pediatric Research, established in 1999.

Finally, however, it is his remarkable influence on those of us fortunate enough to train and to work with him that we most recognize today. His remarkable ability to be there every day for his patients, his capacity to stand behind his colleagues, his ability to listen and to truly hear, his unyielding commitment to excellence, his deep-rooted sense of responsibility and stewardship, and his devotion to his wife Jean Nathan and their family all have been a constant inspiration for us all.

Now David Nathan joins an illustrious group of Harvard faculty: Gamble and Crothers, Diamond and Smith, Janeway and Richmond, and those who traveled through Butler and Barness, Rudolph and Gellis, Haggerty and Katz, who have received this singular honor of the American Pediatric Society. David, we invite you to come forward to receive the respect, gratitude, and deep affection of your colleagues. 